\section{O BERÇO ESQUECIDO DE UMA MULHER SOLDADO}

\section{THE FORGOTTEN CREST OF A SOLDIER WOMAN}

Jaime Magalhães Morais ${ }^{1}$

\section{INTRODUÇÃO}

Maria Quitéria de Jesus, nascida no território da Vila de Cachoeira, se constituiu, em vida, numa das maiores lideranças da Guerra da Independência da Bahia. As pesquisas que tratam sobre essa vultosa guerreira são raras e pouco têm esclarecido acerca de grande parte de sua vida, e isso se acentua quando o tema é sobre a sua infância. Inversamente, muitas municipalidades do Estado têm reclamado a maternidade da heroína. Feira de Santana, Tanquinho, Irará e Cachoeira se revezam em reclamar a sua naturalidade, contudo, não têm apresentado razões suficientemente plausíveis para comprovar a localização do sítio onde se deu o nascimento desta heroína. Outra questão que causa certa surpresa a pesquisadores de outros Estados, é a falta de um referencial de localização para culto à sua memória. A questão aqui posta é: por que o local do nascimento de Maria Quitéria caiu no esquecimento? Esta indagação dá rumos ao tema que tem por objetivo situar o sítio Licurizeiro, local onde Maria Quitéria viveu na infância.

${ }^{1}$ Programa de Pós-Graduação, Mestrado em Memória: Linguagem e Sociedade (PPGMLS), Universidade Estadual do Sudoeste da Bahia (UESB), Campus de Vitória da Conquista, Bahia - Brasil.

E-mail para correspondência: jagamor@gmail.com

\section{RESUMO}

Nascida na então Vila de Cachoeira, mais especificamente na freguesia de São José das Itapororócas, Maria Quitéria de Jesus se destacou na campanha pela independência da Bahia como um valoroso soldado do Batalhão dos Periquitos. A mudança de sua família para o território da povoação de Tanquinho, ainda parte da mesma freguesia, se deu quando Maria Quitéria ainda era criança, e as divisões políticas que vieram a se processar, com o Império e a República, comprometeram as memórias da sua terra natal com o desleixo do Estado e a conivência de grande fatia dos seus condutores. Nesses territórios, a população é caracterizada pela forte miscigenação e absorção dos valores culturais dos nativos. Se ainda restou algum vestígio do antigo sítio, onde os pais de Maria Quitéria viveram e lhe deram vida, muito se deve aos remanescentes que, através dos testemunhos prestados em depoimentos, permitiram rastrear a localização do sítio Licurizeiro.

Palavras Chave: Maria Quitéria. Memória. História. Esquecimento.

\section{ABSTRACT}

Born in Vila de Cachoeira, more specifically in the parish of São José das Itapororócas, Maria Quitéria de Jesus stood out in the campaign for the independence of Bahia as a valiant soldier of the Parachute Battalion. The change of her family to the territory of the village of Tanquinho, still part of the same parish, occurred when Maria Quitéria was still a child, and the political divisions that came to take place, with the Empire and the Republic, compromised the memories of her the homeland with the sloppiness of the State and the largescale connivance of its drivers. In these territories, the population is characterized by the strong miscegenation and absorption of the cultural values of the natives. If there is still some vestige of the old site where Maria Quiteria's parents lived and gave their life, much is due to the remnants that, through the testimonies given in testimony, allowed to trace the location of the site Licurizeiro.

Keywords: Maria Quitéria. Memory. History. Forgetfulness.

Submetido em: 06 de nov. 2017

Aceito em: 06 de nov. 2018 
Temos, como referencial teórico, a obra de Paul Ricceur (2007, p. 80-81), de título A memória, a história, o esquecimento, que se atém, dentre muitos outros temas, à análise dos lugares de culto da memória natural, isto é, aquela que não ultrapassa os limites do que é revisitado pelos indivíduos num grupo que passa a praticar artificialismos como meio de preservação. Quando o próprio Estado não se encarrega de propagar ideias que deslizam sutilmente para baixo do tapete, a intenção de outros grupos é disso tirar proveito. Alguns autores se embalam nas mais fantasiosas versões que acabam por fazer de Maria Quitéria uma heroína ideologicamente imaginada, quando, na verdade, sua vida foi das mais espinhosas.

A metodologia adotada nesta análise se fundamenta nos princípios estabelecidos por Verena Alberti (2004), em seu Manual de História Oral. Já as fontes se amparam no depoimento da Sra. Antonieta Carneiro Magalhães Moraes (2011), registrado em obra que apresenta relação com a vida pregressa, ou pouco referida, da personagem histórica em estudo. Também é usada a entrevista do Sr. Mário Lima de Cerqueira (2015), natural de Santa Bárbara, em razão da proximidade que tem o território do município desta cidade com os limites onde nasceu Maria Quitéria.

A área de estudo aqui é tratada como tabuleiro Paiaiá, assim designada, em princípio, pois apresenta baixo teor de nutrientes e material orgânico que se estendem de norte a sul do atual Estado na parte interna do continente. Os tabuleiros são territórios que acompanham os contornos costeiros carentes de elevações de tal modo que predominam platôs de baixa altitude e fartura de alagadiços. Onde existem elevações consistentes, não mais se constituem como tabuleiro. No mínimo, fica em seu limite São José das Itapororócas, atual distrito de Maria Quitéria, no Município de Feira de Santana, por exemplo. Sua vegetação se caracteriza pela mescla do bioma mata atlântica com a caatinga - mas algumas espécies deste último ambiente são escassas: os cactos, as bromélias e tuberosas como o umbuzeiro -, e se estende das bordas litorâneas até o semiárido, com quem se limita a oeste.

Os povos nativos Paiaiás, nesta fitofisionomia, viviam, desde períodos imprecisos, antes da colonização portuguesa, como observa Abreu (1976, p. 105) na sua obra Capítulos da História Colonial. Os domínios dos Tapuias Paiaiás se estendiam das vizinhanças dos Tupinambás, na costa, até as imediações de Jacobina, no semiárido baiano, e incluíam o tabuleiro, que faz divisa com o rio Paraguaçu/Jacuípe na sua margem esquerda. Muito embora os tabuleiros prossigam em direção ao sul baiano, na margem direita do primeiro rio, eles já eram habitados por outros povos, de forma que o tabuleiro Paiaiá se atém à faixa norte, se espraiando até ao Município de Água Fria, limites com o semiárido, a norte. Territórios estes descritos, desde o início do período colonial, como lugares onde habitavam os povos Tapuias hoje um termo considerado ultrapassado, no entender de alguns especialistas que pesquisam as populações nativas dos sertões. Contudo, a Grande Enciclopédia Larousse Cultural (1995, vol. 2, p. 260-261) ainda traz extensa lista de povos que habitam a Amazônia brasileira, com quantidade significativa de tribos que se autointitulam com esse termo.

Esses domínios Paiaiás foram integrados, na segunda metade do século XVII, às posses de sesmeiros portugueses, donos de grandes exten- sões de propriedades nos sertões, os quais se incompatibilizavam com a catequese dos jesuítas em razão de buscarem áreas para o trânsito das boiadas, uma vez que o gado precisava se reabastecer no deslocamento do semiárido para o litoral. Áreas estas também ocupadas pelas aldeias nativas ricas em água, a exemplo dos rios, lagoas e nascentes, as quais sofriam danos provocados pelo trânsito do gado dos sesmeiros, danos estes que se estendiam à lavoura nativa, e os Paiaiás reagiam conforme suas limitações bélicas, motivo dos pecuaristas contratarem paulistas especializados na préa de outros autóctones que, subjugados, eram levados até os locais de comércio escravista com o objetivo de vendêlos, no que se convencionou por descimentos.

\section{RELAÇÕES INTERÉTNICAS}

No início da colonização portuguesa se avolumaram os problemas, não apenas entre as populações encontradas, mas também entre outros europeus interessados em adquirir parcelas coloniais na América, pois os portugueses visitavam os sertões esporadicamente, até porque a metrópole vivia momentos difíceis por conta da morte inesperada de D. Sebastião, evento este que fez Felipe, rei espanhol, ascender ao trono com a união de ambos os reinos.

As terras mais procuradas eram constituídas de massapê, encontrado no litoral, uma mistura de argila com saibro, muito fértil e, portanto, excelente para a prática da agricultura. Essa característica das áreas litorâneas vinha a calhar com as ambições do reino que tinha projetos de expandir a agricultura da cana a fim de incrementar o comércio do açúcar no continente europeu. Diferente do massapê, os 
solos constituídos de arenito eram considerados "terras fracas", vistas como mais apropriadas aos criatórios de gado, nas afirmações de Souza (1851, p. 71-73). Adiante veremos o que isso implica para seus moradores.

Com isso, salvo expedições de bandeiras baianas, que buscavam apreender nativos Tapuias para fazê-los escravos, e a concessão de sesmarias a nobres portugueses interessados em crescer o rebanho bovino, os sertões só vieram despertar a cobiça do reino já na segunda metade do século XVII. Este jugo das populações Tapuias só viria se consolidar, ainda com vários percalços, em metade do século XVIII, até mesmo nos tabuleiros que ficam contíguos ao litoral.

Assevera o monsenhor Renato de Andrade Galvão (1982, p. 25), em seu artigo - Os povoadores da Região de Feira de Santana - que o sesmeiro João Peixoto Viegas, do reino restaurado de Portugal, recebera uma concessão de sesmaria cuja regulamentação só ocorreu em 1655, mas que ele já ocupava a área de São José das Itapororócas desde 1640, área limite ao tabuleiro, a qual era ambicionada pela riqueza de alagadiços. A partir daí se intensificaram os combates aos Paiaiás, os quais se estenderiam até a década de 1730 , já com o neto homônimo à frente, no século XVIII.

Diante desses fatos que viriam redundar na maior concentração dos Paiaiás no tabuleiro, em fins do século XVII e inícios do XVIII, se formou um embrião da aldeia que anos mais tarde tomou a designação dada pelas autoridades, de Sant'ana da Feira, na freguesia de São José das Itapororócas, termo da Vila de Nossa Senhora do Rosário do Porto da Cachoeira. Isto se devia à fundação da mais nova capela cuja padroeira se tratava de Senhora Sant'ana, e às boiadas que já singra- vam os sertões em direção à Capital se ressentiam de aguadas, fartas nesta área, para o seu suprimento, o que fez crescer o comércio já praticado na feira de ervas e de produtos agrícolas. Concomitantemente, outras populações se juntaram aos Paiaiás, a exemplo de negros fugidos dos engenhos, os quais se incorporavam dentro dos mocambos. Sublinha Juliana Brainer Barroso Neves (2008, p. 77), em sua dissertação de nome Colonização e resistência no Paraguaçu, que muitos mocambos foram localizados dentro do tabuleiro Paiaiá entre o século XVII e XVIII.

Também do reino vieram os ciganos que, em maior número, no passado, serviram de espias, já que se tratavam de populações nômades que desembarcavam e se deslocavam das capitanias a norte, no sentido de Salvador. O percurso empreendido pelos ciganos forçava necessariamente a travessia de áreas dos domínios Tapuias e, com eles, estabelecerem contato. Após ser determinado o itinerário pelos órgãos competentes do Estado, os ciganos deveriam fornecer informações às autoridades, prática observada até mesmo no século XX.

Em seu depoimento, Moraes (2011, p. 103-104) diz que, quando menina, os ciganos eram segregados de tal modo a não terem acolhida nas fazendas dos seus parentes - Carneiros que habitavam no atual distrito de Jaguara, antiga povoação do Bom Despacho, hoje um dos distritos do Município de Feira de Santana. Inversamente, seus parentes, pela descendência paterna, alguns deles delegados de polícia, se relacionavam muito bem com os ciganos ao ponto de dar pouso em sua fazenda e entre eles contarem até com afilhados.

Ainda, essas relações dos nativos não se limitavam apenas aos negros ou aos ciganos, eles também mantinham contato com as forças de opressão das milícias, que defendiam a ordem imposta pelo reino. Apesar da maioria dos milicianos que estabeleceram combates nos tabuleiros se constituírem de paulistas que se aventuraram pelos sertões, também havia outras tropas deslocadas da metrópole para garantir os territórios averbados à colônia. Assim, foram enviadas famílias dos militares de patente, nobres de armas de descendência entre judeus em Portugal, as quais deveriam adquirir dos sesmeiros, via compra, parcelas das sesmarias para produzirem gado nas fazendas e, com isso, facilitar o jugo dessas populações.

\section{O SÍTIO LICURIZEIRO}

A própria Sra. Antonieta Moraes (2011), que descende dos Carneiros estabelecidos desde os tabuleiros até os sertões de Jacobina, já se faz numa descendente de Cristãos Novos que em inícios do século XVIII adquiriram fazendas nesses territórios. Essas levas de colonos cresceram sensivelmente ao longo do século, de maneira que tanto Quitéria Maria quanto Gonçalo Alves de Almeida, pais de Maria Quitéria - na obra de nome Diário de uma viagem ao Brasil, da inglesa Maria Graham, em sua tradução de 1956 , já serem descritos como portugueses. Na mesma tradução, em nota de rodapé, se corrige a informação, observando que Gonçalo Alves se declarara brasileiro em seu testamento (Idem, p. 329). Lembrando que esse termo "brasileiro" ainda era recente no vocabulário português, mesmo no Brasil.

Até então a migração das mulheres portuguesas não era nada comum à colônia, todavia, como já alertado, as famílias judias acompanhavam os militares de patente nas suas novas 
propriedades, nos sertões adquiridas. A simbiose dessas etnias com a marcante absorção da cultura Tapuia, aqui tem nos indivíduos a designação de tabaréu, tratamento este mais conhecido aos habitantes dos sertões baianos e que herda dos nativos toda uma carga de saberes. Isto não significa uma característica física comum a todos, mas uma prática, um procedimento que tanto é encontrado nos estratos sociais mais pobres como nos mais representativos que incluem os militares de patente. Até porque, mesmo prevalecendo, entre estes militares os casamentos com parentes mais próximos, também havia concubinas de descendência entre os nativos, as quais lhes geraram filhos bastardos em maior número, mas também como fruto de casamentos legalizados.

Na mesma obra, Graham traz uma descrição física de Maria Quitéria, observada pela autora, que se constitui de grande valia "[...] Sua mãe era também portuguesa; contudo, as feições da jovem, especialmente os olhos e a testa apresentam os mais acentuados traços dos índios" (Idem, ibidem). Como esta autora esteve pessoalmente com a protagonista dos fatos, pode ao leitor parecer não haver sombra de dúvidas na narrativa, mas isso não deve ser entendido num contrassenso da escritora, antes num alerta.

As informações prestadas por Maria Quitéria precisam ser analisadas com certa cautela, considerando pelo menos dois fatores essenciais no diálogo. Primeiro, sua condição de mulher que já contava trinta anos, ainda por ser alfabetizada, que saíra da sua morada com o objetivo de lutar pela independência e, com isso, se desentendera com o pai a quem amava e buscou meios de se reaproximar, viajando até a Capital do Império com a ideia fixa de se valer do Imperador para moderação dos ânimos exaltados em sua residência. Esse particular encontra paralelo, inclusive, ao caos que se seguiu ao fim do conflito e permaneceu pelas duas décadas seguintes, no território da já Vila de Sant'ana da Feira que abrangia outros territórios de povoações vizinhas e das fazendas de propriedade de Gonçalo Alves.

O segundo aspecto, agora ligado à autora inglesa, se refere à sua condição de estrangeira que não dominava a Língua portuguesa suficientemente para entender os regionalismos próprios aos nativos do tabuleiro Paiaiá, cuja averbação territorial ainda não completara um século. A língua vernácula dos Paiaiás, durante a catequese dos jesuítas, se modificara em consequência da Língua Tupinambá ser a adotada como Língua Geral do Brasil, assim descrito no artigo de Ana Palmira Bittencourt Santos Cassimiro (2005, p. 182-205), intitulado de Cartilhas e Catecismos usados no Brasil Colonial. Apesar da exigência do idioma Português já ser editada no reinado de D. João V, os religiosos resistiam a cumpri-la, e com a expulsão dos jesuítas, em 1759, o ensino ficou em aberto, privando as populações que habitavam em áreas de recente inclusão à colônia de qualquer ensino, e até de se cumprir a determinação pombalina em ministrar aulas em Língua portuguesa, pela carência de professores, mesmo na Capital baiana.

Portanto, havia um enorme fosso com relação ao contato que se estabeleceu entre as duas Marias e isso fica mais visível nas descrições geográficas que são feitas da área onde vivia Maria Quitéria. Há vários equívocos na listagem dos rios que atravessam a fazenda, as suas localizações, por exemplo, que têm nomes específicos, de modo a serem confundidos com outras correntes fluviais, que se entende do mesmo modo ter embaralhado a compreensão da autora no que diz respeito à origem dos pais de $\mathrm{Ma}$ ria Quitéria; contudo, na obra de Graham (1956) aparecem ideias mais claras, a partir da descrição da visita dos emissários de Cachoeira.

Tido pelos críticos como maior biógrafo da belingerante, Pereira Reis Júnior (1953, p. 17), na obra $M a$ ria Quitéria, relata que a mãe dela se chamava Quitéria Maria de Jesus, nascida em São José das Itapororócas, mesmo local de natalidade de Gonçalo Alves de Almeida - pai de Maria Quitéria. Mais relevante até do que a naturalidade dos pais, seria dizer que independentemente de serem portugueses ou brasileiros, eles se viram forçados a incorporar os valores que encontraram na cultura local, coisa mais arraigada ainda entre os seus filhos.

\section{A inglesa Graham}

também dá pistas de onde teria nascido o pai de Maria Quitéria, quando afirma ter a heroína traços físicos que denunciam um parentesco com nativos, seja pelos olhos ou pela parte frontal da testa. Não necessariamente quer isto dizer que para ser um tabaréu se faz necessário trazer traços físicos dos nativos, mas uma absorção cultural de forte penetração nos portugueses ou em outras etnias que migraram para os sertões baianos.

Se trazia traços dos nativos, alguém da família tinha sangue Tapuia e, nesse caso, parece certo que a família de Gonçalo Alves portasse esse gens proveniente de uma miscigenação anterior, já que aos homens do período era comum ter uma vida aventureira, enquanto que das mulheres portuguesas se exigia uma vida dedicada à polidez e à clausura familiar. Algum dos ancestrais de Gonçalo Alves tinha mãe nativa. Quanto à mãe de Maria Quité- 
ria não se sabe ao certo, diante das confusões anteriores a que se expôs a autora inglesa. Reis Júnior (1953), em suas conclusões, se depara com vasto período que o distancia dos fatos e comprometem informações mais precisas, já que não se apoia em qualquer documento comprobatório. Assim, um novo diálogo com os antigos moradores pode ter maior proveito.

Descrevendo características de áreas contíguas ao local da sua procriação, é elucidativo o depoimento do Sr. Mário Lima de Cerqueira (2015, p. 1), nascido na fazenda Tapuio em 1944, ao asseverar que seu avô, originário de Santa Bárbara - área do tabuleiro Paiaiá, que se localiza no limite entre os Municípios de Santa Bárbara e Santanópolis - vizinho ao lugar da infância de Maria Quitéria, se dedicava ao mesmo ofício de Gonçalo Alves. Narra ele que a maioria das casas de moradia eram pequenas e construídas de adobes, casas estas caracterizadas por poucas divisões, e que os mais pobres faziam casa de taipa (um legado dos povos Tapuias) como a maioria das populações pobres na época de criança de Maria Quitéria, e estes pobres se valiam da agricultura com poucos recursos na pecuária.

Ressalte-se que nesse período as escaramuças com os nativos ainda eram comuns, de forma que Maria Quitéria aprendeu a atirar com armas de fogo, não apenas porque caçava, mas como uma prevenção contra um ataque inesperado dos nativos. A vida de tropeiro exercida por seu pai não permitia maior assiduidade na casa; isso exigia alguém que desse maior segurança na sua ausência e até certa medida esta responsabilidade era dada a Maria Quitéria cuja mãe faleceu quando a futura soldado ainda contava com apenas dez anos, assumindo os cuidados com seus outros dois irmãos mais novos até o novo casamento do pai, ocorrido cinco meses depois. Daí crescer o desejo em assegurar a soberania territorial.

Durante a entrevista concedida a Maria Graham, Maria Quitéria passou alguns detalhes a esse respeito: "[...] As moças aprendem o uso de armas de fogo, tal como seus irmãos, seja para caçar, seja para defenderemse dos índios brabos" (DEPOIMENTO, apud GRAHAM, 1956, p. 330). Até mesmo Gonçalo possuía cinco escravos, quando sua primeira esposa faleceu, de forma a ser possível, nesses momentos de vulnerabilidade, a ocorrência de fugas ou revoltas, ainda que se argumente o escravismo ter um tratamento mais brando comparado ao que ocorria no litoral. Seria pertinente que um parente mais próximo cuidasse dos filhos de Gonçalo Alves, em sua ausência, não só para garantir-lhes a defesa contra os nativos mas também livrá-los do risco dos cativos os fazerem reféns.

Muito embora no seu depoimento Maria Quitéria não faça referência a outros cultivos além do algodão, no tabuleiro Paiaiá, se faz comum ainda, na atualidade, a lavoura dos cereais, a exemplo do milho e do feijão, e dos tubérculos, mandioca e batata, na qual mais se empregava a mão de obra escrava. O cultivo do amendoim também é realizado, grão de grande aceitação entre o público consumidor, com ambulantes fazendo a distribuição na modalidade cozida ou mesmo torrado e acondicionado em pequenas poções. $\mathrm{O}$ amendoim abastece ainda hoje os bares, as mercearias e os supermercados. Normalmente os cativos das fazendas se prestavam a essa tarefa, como ambulante no comércio varejista e/ ou entregando nos postos de revenda.

Outro dos mais difundidos cultivos praticados, mesmo no início do século $\mathrm{XX}$, se trata do tabaco, um dos mais penosos para o lavrador, porém dos mais valorizados entre os produtos usados para o escambo de pessoas escravizadas, trazidas da África. Os tropeiros faziam o transporte desses variados produtos até o porto de Cachoeira e, via embarcações, eram levados até ao porto de Salvador, na fala de Cerqueira (2015, p. 1). Gonçalo não deveria ignorar a necessidade da prática dessas outras lavouras na sua propriedade, não apenas porque já era uma tradição, mas, sobretudo, em razão desses víveres ajudarem no sustento dos moradores da sua casa, que se estendiam ao efetivo sob jugo, os quais se envolviam nessas atividades.

A baixa produtividade das áreas de tabuleiro não permitia que rendessem boas safras, exceto se o solo fosse melhor trabalhado com fertilizantes. A tradicional fertilização era muito lenta para enriquecimento do solo, o que fazia míster o consórcio da pecuária com o objetivo de se aproveitar do esterco bovino como adubo, o qual misturado à terra, desde que as precipitações se dessem de forma regular, atendia de bom grado às expectativas.

Sebastião da Rocha Pita (1880, p. 12), em sua obra de nome História da América Portuguesa, chama a atenção detalhando como os lavradores da mesma área, também tratada por campos da Vila de Cachoeira, desse consorciamento tinham carência. A pecuária foi mais praticada no período colonial em áreas mais distantes da costa, isto para evitar que o gado invadisse áreas ocupadas com a monocultura da cana e provocasse prejuízos aos senhores de engenho, no litoral estabelecidos.

O algodão, nessa fase, ganhava força com a procura da matéria 
prima pelos ingleses; certamente isto ajudou na definição de Gonçalo recair nesse cultivo, até porque ele estava bem informado das mercadorias mais valorizadas, e este era um produto que exigia pouco dos animais de carga. A distância de Cachoeira não era das maiores, de modo que o transporte poderia ser feito mais rapidamente de outras áreas do sertão e até de outras capitanias.

Ao que tudo indica, Cerqueira vivia numa propriedade com o filão de terras mais rico, ainda que pertencente ao tabuleiro, com se verifica nesse trecho:

Trabalhava de capinar terra, plantar feijão, milho, mandioca. Sempre quando tava novinho, ajudano meu pai. Lá era uma área de caatinga misturada com área de tabuleiro um pouquinho. Era tanto que os pastos era tudo de capinho. A terra preta. E sempre tinha um lugar, a terra areada e tudo, aí a gente prantava mandioca, todo tipo de fruta a gente plantava, mas não dava todas. Dava era goiaba, jabuticaba, é... melancia, abóbra, andu, mangalô, todas essas variedades dava lá. (CERQUEIRA, 2015, p.4).

Não é esta uma característica extensiva a todo o tabuleiro Paiaiá cujo solo arenoso, sem nutrientes suficientes para o desenvolvimento das plantas, aumentava os custos do investimento em plantio, enquanto ali próximo, ainda no território do atual Município de Feira de Santana, se encontram solos bem mais ricos, de áreas do semiárido. As dificuldades de plantio em solo arenoso certamente foi um dos fatores que determinou Gonçalo a vender a propriedade, naturalmente agravado pela morte de suas duas primeiras esposas, o que ocasionou más recordações aos filhos, na tenra idade vivendo.

A condição econômica de Gonçalo, no período inicial de casado e da sua idade produtiva, não lhe permitia ficar muito tempo sem fazer novas viagens que lhe rendessem algum lucro para a manutenção da casa, o que seguramente ele fazia acompanhado de alguns dos cativos enquanto outros se dedicavam aos trabalhos da fazenda. Algum adulto da sua confiança se fazia presente nessas ocasiões para não deixar as crianças a descoberto. Tais condições fizeram com que ele contraísse novo matrimônio, pois não se sentia confortável em ocupar terceiros com cuidados que não lhes eram de sua alçada.

Mas a atrocidade do destino não lhe ajudava muito, pois a segunda esposa logo depois veio também a falecer, repetindo as dificuldades: os gastos com o funeral, com as tramitações burocráticas dos inventários e a escassez de tempo para se dedicar ao seu ofício de tropeiro, sem contar com o desajuste psicológico da família, provocado pelas perdas familiares (REIS JUNIOR, 1953, p. 22). Até os doze anos, Maria Quitéria permaneceu no sítio Licurizeiro, quando Gonçalo Alves resolveu migrar do tabuleiro Paiaiá para um território de solo mais rico, localizado nas imediações de Tanquinho, já na área do semiárido.

\section{OS MILITARES DE PATENTE}

Parece haver certa tendência dos povoadores portugueses evitarem se estabelecer no tabuleiro Paiaiá como pecuaristas, ainda que a Sra. Antonieta Moraes tenha nascido na fazenda Canavieira, hoje averbada ao distrito sede do Município de Feira de Santana com sua atual inclusão nos limites do bairro da Pampalona, como afirma no depoimento:

Sou descendente da família Carneiro que se radicou em Feira de Santana, nascida no dia 13 de junho de
1919, na fazenda Canavieira, em São José das Itapororócas, cuja família da parte materna já residia na fazenda Roça da Serra desde muito tempo, antes do falecimento do meu pai em 1926, localizada no Distrito de Bom Despacho na face sudoeste da Serra das Sete Cabeças, parte da propriedade posteriormente herdada do meu avô pela minha mãe (MORAIS, 2011, p. 75).

Observa-se, no relato, a afirmação que os Carneiros estabelecidos no Bom Despacho, atual distrito de Jaguara, já habitavam na região desde muito tempo, o que significa dizer, não apenas décadas, mas, por quase três séculos. Seus ancestrais, como adiante veremos, se fixaram em inícios do século XVIII, pelos sertões.

Salvo os que migraram para a sede, no século XX, que se localiza na área mais alagada do tabuleiro Paiaiá, raros foram os que adquiriram propriedades nesse espaço. No grande território ocupado pelo semiárido baiano vai se espraiar a maior concentração dos Carneiros no Estado, enquanto que no Município de Feira de Santana, sua difusão se ateve às bordas do tabuleiro, onde se verifica mais escassez de precipitações de chuvas, área que abarca parte das caatingas.

A mais antiga referência encontrada para a serra das Sete Cabeças data de 1850 com o coronel José Batista Carneiro, adquirindo, via compra, um lote de terras, afirmação que encontra respaldo no Inventário analítico da documentação histórica do monsenhor Renato de Andrade Galvão, obra creditada a Maria de Fátima Hanaque Campos (1998, p. 59). Mas, ainda assim, no século anterior, o mesmo volume traz na página precedente, em data sem precisão, na segunda metade do século XVIII, o registro que o português Custódio Ferreira Passos casado com a tia do coronel José Batista Carneiro, de nome Rosaura - 
através de ação requer um traçado dos limites da fazenda Imbuzeiro junto à justiça. Local este situado próximo ao rio de Jacuípe, como também à serra das Sete Cabeças, o que significa dizer que a área passou a ser ocupada naqueles idos.

Há vários outros documentos que de igual modo são catalogados nesta obra, os quais se referem ao pai do coronel José Batista Carneiro, o capitão João Batista Carneiro, ou ao seu avô Antônio Carneiro da Silva a reclamarem títulos de propriedade, no século XVIII, em territórios vizinhos. Foram esses militares de patente que se estabeleceram com suas fazendas nos sertões, da então Capitania da Bahia.

Luis Cleber Moraes Freire (2010, p. 191-193), em seu estudo genealógico desta família, Os Carneiros no sertão da Bahia, se reporta ao pai do capitão João Batista. Este teria emigrado de Portugal, se casando em Água Fria em 1730 e tinha por nome Antônio Carneiro da Silva. Se casara com uma das filhas de Bernardo da Silva, sendo ela natural de Serrinha e levava o nome de Ana Maria da Silva, e residiam na fazenda São Bartolomeu, situada em Riachão do Jacuípe. Dali, sua geração de nada menos que doze filhos se ligaria em matrimônios a outras muitas famílias de parentes, ao se fixarem num raio de vizinhanças que abrangiam quilômetros em todas as direções com João Batista Carneiro se estabelecendo na fazenda Santa Rita, em São José das Itapororócas, fruto de compra em mão de Lourenço Justiniano do Valle Sá, um dos descendentes do sesmeiro João Peixoto Viegas.

O capitão João Batista Carneiro tanto quanto o alferes Custódio Ferreira Passos se estabeleceram como fazendeiros, antes que Gonçalo Alves adquirisse o sítio Licurizeiro, com esposas e seus filhos mais velhos, ainda adolescentes. Eles faziam parte das relações de Gonçalo Alves, após o falecimento da sua primeira esposa, como veremos a seguir.

Ambos foram requisitados como avaliadores dos bens deixados por D. Quitéria Maria de Jesus e Gonçalo Alves, em janeiro de 1803, quase um ano depois do óbito da mulher (REIS JÚNIOR, 1953, p. 21). Contudo, sete meses antes, Gonçalo Alves já havia contraído núpcias com D. Eugênia Maria dos Santos, na Igreja de São José das Itapororócas.

Não é uma distância das mais elásticas, para se deslocar montado, a que separa o sítio Licurizeiro da sede da freguesia de São José das Itapororócas. Diria que léguas sem conta eram cobertas pelas cavalgaduras nesta ocasião, a exemplo do gado tangido pelos vaqueiros do Maranhão e Piauí, ou até de Minas Gerais e Goiás, para ser vendido em Salvador, enquanto o trajeto do sítio Licurizeiro até São José das Itapororócas, pela via mais curta, não passava de vinte e cinco quilômetros. Era verdade que os nubentes e os convidados precisavam ter mais conforto no deslocamento, mesmo porque o aparato que envolve a cerimônia requer certos cuidados com a indumentária e ornamentos. Por isso havia a alternativa de as famílias perfazerem o trajeto em carros de boi, pela menor distância.

O capitão João Batista foi convidado como um dos padrinhos do casal. O ritual de casamento não se revestiu dos mesmos faustos anteriores, em virtude do clima pesado que ainda envolvia a morte de D. Quitéria, mãe das crianças, que ocorrera no início deste mesmo ano, de 1802 (Idem, ibidem). Portanto, se observa que antes de João Batista e Custódio
Ferreira se apresentarem como avaliadores, já João Batista tinha sido padrinho do segundo casamento de Gonçalo Alves, o que o credencia como uma das mais influente amizades.

Para quem habitava já há algum tempo na fazenda Santa Rita e acumulava certo conhecimento com relação à administração das propriedades, em razão de ter nascido no semiárido, nada impedia que o capitão João Batista sugerisse a Gonçalo Alves vender seus bens no sítio Licurizeiro e adquirir outra propriedade em áreas mais produtivas no semiárido, em respeito à sua opinião balizada. Até porque a fazenda Santa Rita era uma possessão das mais invejadas pelo progresso que registrara sob a batuta do capitão João Batista, que certamente se solidarizava com aqueles momentos difíceis do tropeiro.

Dos vários outros ramos que se ligavam à mesma família, assim distribuídos pelos sertões, apenas alguns descendentes de João Batista Carneiro se fixaram em São José das Itapororócas, mais propriamente herdando parcelas da sua posse, situada no limite com o semiárido, enquanto crescia assustadoramente o número deles pelo território da povoação do Bom Despacho, portanto, fora do perímetro do tabuleiro (FREIRE, 2010, p. 2015-2018). Não foi um acaso esta preferência já que seria um investimento que demandava outras tarefas ligadas à adubação das terras.

É fato que Gonçalo Alves vendeu o sítio Licurizeiro, e com os valores resultantes da transação foram criadas as condições de aquisição do imóvel que deu o nome de Serra da Agulha, localizada em Tanquinho. Pelo que dizem os biógrafos de Maria Quitéria, seu pai teve outras propriedades além dessa última, as quais foram adquiridas nos anos posteriores ao 
falecimento da sua segunda esposa, o que revela ter decidido corretamente quando se desfez do sítio Licurizeiro. São listados pelo menos mais dois sítios, nem sempre situados no semiárido. Mas se delineia que os três primeiros filhos de nome Maria Quitéria, seu irmão Luís e a irmã de nome Josefa, todos nasceram no sítio Licurizeiro.

Gonçalo Alves não era um homem de posses em sua vida de solteiro, e as dificuldades se estenderiam à sua vida de casado. Ele viveu, com a primeira e a segunda das três mulheres com as quais se relacionou, numa casa de taipa, coberta com palmas de licurizeiro, termo esse que coincidentemente deu nome à sua também primeira propriedade (REIS JÚNIOR, 1953, p. 17). Dificuldades não só de ordem econômica, mas de naturezas diversas, foram por ele enfrentadas, como a morte da primeira e da segunda esposa. Cada óbito lhe obrigava a nova tentativa de encontrar uma companheira que dividisse as tarefas de casa, educasse os filhos e gerenciasse o lar.

No tempo que permaneceram naquele sítio, a casa era frágil, não suportaria longos anos sem manutenção, e o novo proprietário teve necessidade de construir uma morada maior e mais resistente que aquela, de modo a melhor acomodar os seus familiares. Fato é que não se sabe ao certo se foi demolida esta casa ou se os cupins e as intempéries do tempo se encarregaram de derruí-la. Todavia, se não mais existe a mesma sede, ao menos a propriedade ficou intacta.

Atentemos à narrativa da Sra. Antonieta Moraes:

Em 1934, a professora Áurea casou-se com o Sr. Abílio Santa Fé Aquino. Ele é natural de Irará. Contava que quando foi para Tanquinho, saiu da fazenda Licurizal de propriedade do Sr. Benzinho (Elpídio Marques de Oliveira), a mesma que Maria Quitéria nasceu (MORAIS, 2011, p. 105).

A Sra. Antonieta foi aluna da professora Áurea e com ela conviveu bom tempo em Tanquinho, quando ouvia os relatos sobre Maria Quitéria. A professora Áurea era sobrinha em terceiro grau, já que seu pai, Manoel Cordeiro era neto de Teresa, uma das irmãs da guerreira, fruto do terceiro matrimônio de Gonçalo Alves. Posteriormente, D. Antonieta também seria professora do Município de Feira de Santana, atualmente aposentada, vivendo na ancianidade ao presenciar 99 contornos terrestres ao redor do astro rei.

Nascido em 1911, o senhor Abílio Santa Fé Aquino (2006) ainda era natural de Irará, que adiante teria dividido parte de seu Município (informação verbal). ${ }^{2}$ Não significa isso dizer que Maria Quitéria é iraraense, nem muito menos que o sítio se localiza em seu território, em função das novas divisões políticas feitas no Império ou na República. Todavia, a fazenda Licurizal foi legada à descendência do senhor Elpídio (Benzinho), a qual ainda leva a mesma designação, diferentemente da mudança do nome Licurizeiro, que deixara memórias amargas na família de Gonçalo Alves e muito mais a Maria Quitéria, que dele nada além do afeto, criação e virtudes, enquanto teve vida, herdou.

\section{CONCLUSÃO}

Os licurizeiros são conhecidas palmeiras silvestres e, certamente, marcavam a paisagem da propriedade, este o motivo de o nome da fazenda ter

${ }^{2} \mathrm{Em}$ visita informal à sua residência em Tanquinho, o senhor Abílio Santa Fé Aquino, ex vereador em Feira de Santana no período de 1948 a 1951, que também foi proprietário dos Laticínios Santa Fé e da fazenda Serra da Agulha, com gracejos afirmou que nascera "no dia 11 , do 11 , de 1911" (in memorian). permanecido, com ligeira derivação no título. É algo comum aos novos proprietários escolherem entre batizar esses imóveis com novo nome ou manter a mesma designação. Nesse caso, até em respeito à família de Gonçalo Alves, o nome foi trocado para evitar recordações desagradáveis a cada alusão feita à propriedade, principalmente as dificuldades que ele passara com o primeiro e o segundo casamento.

Em 1921 foi criada a povoação de Quaresma, dentro dos limites do Município de Irará, no Estado da Bahia. Em 1937, com a nova divisão territorial, a povoação passou a se chamar Santanópolis e, a partir do governo de João Goulart, que se estendeu de 1961 até 1964, vários municípios foram criados no Estado da Bahia, conforme dados do IBGE (2010). Entre eles Santanópolis, que foi promovido a Município em 1962 e assim teve seu território desmembrado de Irará. Os números mais atuais fazem menção de 8.776 habitantes em 2010, com uma projeção para 2018 de 8.920 pessoas. Com isso, a fazenda Licurizal, que estava dentro do território de Irará, se desvinculou dessa unidade política e administrativa, com a propriedade passando a compor o Município de Santanópolis. A título de curiosidade, pode-se afirmar que Maria Quitéria é natural de Cachoeira, ainda em vida foi feirense e como tal faleceu.

A fazenda Licurizal, antigo sítio Licurizeiro, que está localizada bem próximo da sede do Município de Santanópolis, dentro deste território, ainda pertence a um dos descendentes diretos do senhor Elpídio Marques de Oliveira, e ali se deu o nascimento de Maria Quitéria (MORAIS, 2011, p. 105). O odontólogo Dr. Romeu Campos, seu neto, já se desfez desse bem em favor de outro primo, que, de igual modo, também é neto do senhor Elpí- 
dio.

O Estado, nesse caso, é o maior responsável pela amnésia da maioria da população, o qual a cada nova divisão política também descarta memórias caras à identidade de seus habitantes. A Bahia vivia um momento particularmente delicado em razão de, nas décadas à independência posterior, viver a transição de uma antiga liderança política, feita por nobres proprietários de engenho, para a zona de conforto e equilíbrio institucional do novo segmento composto de banqueiros, agiotas e traficantes de escravos. Esse último setor ainda carecendo de uma definição no investimento do capital, com o escravismo em vias de ser extinto.

Enquanto isso permanecia insolúvel, uma desordem nos poderes se estabeleceu por conta da indefinição legislativa e das pressões internacionais para se dar fim ao tráfico de escravos da África. Nessas incertezas políticas, no cenário de falta de definições nos quadros sociais de comando e vivendo a duras penas, cega, sem contar com ajuda dos que dela mais precisaram, veio Maria Quitéria falecer em 21 de agosto de 1853 (REIS JÚNIOR, 1953 , p. 71). Sua fibra the rendeu louvores até daqueles que a exploravam em vida.

Todavia, se para a família de Maria Quitéria a lembrança do sítio Licurizeiro era uma memória dolorosa demais para ser recordada, não devemos negligenciar que ali o tabuleiro Paiaiá teria dado e mantido a vida de uma inquestionável personalidade. Assim como o tabaréu se faz cada vez mais esquecido de sua gênese, o local de nascimento de Maria Quitéria, que tanto quanto ela foi desdenhado, reclama um memorial de pouco interesse da burguesia e dos seus representantes parlamentares. Que a mesma morosi- dade - condenável, registrada em seu período de vida, para se dar solução ao inventário dos bens de Gonçalo Alves -, não seja causa de protestos na atualidade para que celebremos sua memória.

\section{FONTES}

CERQUEIRA, M. L. de. Mario Lima de Cerqueira. Entrevista [mar. 2015]. Entrevistador: "Autor". Feira de Santana: Bairro Brasília, 2015, 2 DVD (72 min.). Transcrito em 13 laudas.

MORAES, Antonieta Carneiro Magalhães. In: MORAIS, Jaime Magalhães. Memórias de uma Cristã nem tão No$v a$, num Sertão nem tão Velho. Feira de Santana: [s. n.], 2011, 127 p.

\section{REFERÊNCIAS}

ABREU, João Capristano de. Capítulos da História Colonial. 6 ed. Rio de Janeiro: Civilização Brasileira, 1976.

ALBERTI, Verena. Manual de História Oral. Rio de Janeiro: FGV, 2004.

CAMPOS, Maria de Fátima Hanaque [et al.]. Inventário analítico da documentação histórica do acervo do monsenhor Renato de Andrade Galvão. Feira de Santana: Centro de Pesquisa e Documentação de Feira de Santana, UEFS, 1998.

CASSIMIRO, Ana Palmira Bittencourt Santos. Cartilhas e catecismos usados no Brasil Colonial. Revista Educação em Questão. Natal, v. 22, 8, 182-205, 2005. Disponível em:

<https://periodicos.ufrn.br/educacaoem questao/article/view/8364/6021>.

Acesso em: 23 set., 2018.
FREIRE, Luis Cleber Moraes. Os Carneiros no Sertão da Bahia. In: Revista do Instituto Genealógico da Bahia, $n^{\circ} 24$, Salvador: Instituto Genealógico da Bahia, abril/2010, p. 190-226.

GALVÃO, Mons. Renato de Andrade. Os povoadores da região de Feira de Santana. Sitientibus, Feira de Santana, n. 1, 1, 25-31, 1982. Disponível em: <http://www2.uefs.br/sitientibus/pdf/1/ povoadores_da_regiao.pdf $>$. Acesso em: 23 set., 2018.

\section{GRAHAM, Maria. Diário de uma} viagem ao Brasil, tradução de Américo Jacobina Lacombe. São Paulo: Companhia Editora Nacional, 1956.

\section{GRANDE ENCICLOPÉDIA} LAROUSSE CULTURAL, Vol. 2. São Paulo: Larousse/Nova Cultural Ltda, 1995.

\section{INSTITUTO BRASILEIRO DE GEOGRAFIA E ESTATÍSTICA (IBGE). Histórico dos Municípios. 2010. Disponível em: <https://cidades.ibge.gov.br/brasil/ba/s antanopolis/historico $>$. Acesso em: 23 set., 2018.}

\section{REIS JUNIOR, Pereira. Maria}

Quitéria. Rio de Janeiro: Ministério da Educação e Cultura, 1953.

NEVES, Juliana Brainer Barroso. Colonização e Resistência no Paraguaçu - Bahia, 1530 - 1678. Recife: UFBA, 2008. f. 84. Dissertação (Mestrado em História Social), Faculdade de Filosofia e Ciências Humanas, Recife. Disponível em:

$<$ https://repositorio.ufba.br/ri/browse?t ype $=$ author $\&$ value $=$ Neves $\% 2 \mathrm{C}+\mathrm{Julian}$ 
a+Brainer+Barroso> . Acesso em: 23

set., 2018.

PITA, Sebastião da Rocha. História da América portuguesa. $2 \mathrm{ed}$, revista e anotada por J. G. Goes. Lisboa: Biblioteca Nacional, 1880. Disponível em:

$<$ https://archive.org/stream/historiadaa meric01 roch\#page/12/mode/2up>.

Acesso em: 23 set., 2018.

RICCEUR, Paul. A memória, a

história, o esquecimento, tradução de Alain François [et al.]. Campinas:

UNICAMP, 2007.

SOUZA, Gabriel Soares de. Tratado descritivo do Brasil em 1587. Rio de Janeiro: Tipografia Régia, 1851.

Disponível em:

<http://www.dominiopublico.gov.br/d ownload/texto/me003015.pdf>.

Acesso em: 23 set., 2018. 